How to cite this article:

Sulaiman, S. (2020). Females in governance and corporate tax avoidance: The moderating effect of accounting conservatism. Malaysian Management Journal, Vol. 24(July), 165-193. https://doi.org/10.32890/mmj.24.2020.9921

\title{
FEMALES IN GOVERNANCE AND CORPORATE TAX AVOIDANCE: THE MODERATING EFFECT OF ACCOUNTING CONSERVATISM
}

\author{
SALAMI SULEIMAN \\ Department of Accounting \\ Ahmadu Bello University, Zaria, Nigeria \\ *Corresponding author:suleiman_salami@yahoo.com
}

\begin{abstract}
High cash outflow in the form of corporate taxes reduces the corporate firms' liquidity, available funds for re-investment and growth opportunities. Corporate firms' attention is therefore geared towards ensuring minimum tax liability. The purpose of this study is to examine the effect of females' presence in the governance on corporate tax avoidance, moderating for the role of accounting conservatism. The study is based on the companies listed on the Nigerian Stock Exchange and utilised the ex-post factor research design. The panel corrected standard regressions was employed to test the hypothesis. Female CEO, percentage of female directors and presence of female in the audit committee have significant positive effects on tax avoidance. The moderating for accounting conservatism, the percentage of female directors on the board and female director presence in the audit committee remains significant. The findings may be of interest to the academic researchers, investors and regulators. For academic researchers, it is interested in discovering whether females' presence in the governance affect tax avoidance and the moderating role accounting conservatism. For investors, it shows that women in the boardroom can improve the bottom line financial performance through tax reduction strategies.This study
\end{abstract}


extends the existing literature by examining the mediating role of accounting conservatism on the relationship between females in governance and tax avoidance in the Nigerian context.

Keywords: Tax avoidance, females in governance, accounting conservatism, female CEO, Nigeria.

Received: 15/5/2020 Revised: 10/8/2020 Accepted: 13/8/2020 Published: 30/8/2020

\section{Introduction}

Tax avoidance is the outcome of corporate governance structures of firms. It is well known that the stakeholders' interest may be conflicting; thus the boards of directors need to ensure a balanced compensation. This is achieved at a point where all stakeholders attain the maximum benefit without a reduction in the benefit of any stakeholder. Although, females on the boards have been explored extensively, not much is established about the role of corporate board with regards to gender diversity on the tax avoidance practices.

Nevertheless, the nexus between female in governance and tax avoidance may be better explained by accounting practice. That is, other factors like conservative accounting practice may be utilised to defer tax payments (Watts, 2003). Accounting conservatism is an essential attribute of quality financial statements since it improves the reliability of financial reporting by enhancing supervision of managers and contracts (Ball, 2001). Conservatism involves the timely recording of expenses compared to gains and discourage overvaluation of firms (Wang, 2015). Proponents of accounting conservatism suggest that it aids stockholders, by limiting the management's opportunistic behaviour (Garcia, Beatriz, \& Penalva, 2005).

In relation to how an increase in women on the board affects tax avoidance, there exists conflicting opinions. The proponents of women directorship based their argument on risk aversion theory that women and men take different ethical decision based on the riskiness of the decision (Olayinka, Oyenike, \& Francis, 2016). The opponents of female representation on the board opine that the increase in female directors does not enhance successful tax minimisation (Khaola \& Ali, 2012). Women generally have poor attendance record compared to men and take less risky decisions (Francis, Hasan, Wu \& Yan, 2014). Kim and Jung (2007) showed that the tax costs motivate unconditional conservative accounting. This study also argues that female presence on the board may not directly account for the variance in corporate tax avoidance among firms, thereby investigating the moderating role of accounting conservatism. 
Prior studies show a linkage governance structure corporate accounting scandals. These are largely attributed to unethical accounting practices. That is, companies engaged in aggressive earnings management have high effective tax rates with inadequate cash to offset. One variant of these unethical accounting practices is large book tax differences (Frank, Lynch, $\&$ Rego, 2004). This entails reporting large sums as declared profits to the shareholders while the tax returns show lower taxable profits. This may be applicable to Nigerian firms where the contribution of corporate firms to internally generated revenue is low.

There exists little empirical evidence on whether females in governance influence tax avoidance in Nigeria. While Aisha (2017) examined the impact of corporate governance mechanisms on tax avoidance, Olayinka et al. (2016) examined the impact of gender diversity on tax aggressiveness of listed deposit money banks in Nigeria. Using effective tax rates to capture tax avoidance may lead to measurement error using Nigerian data. Olayinka et al. (2016) found an insignificant impact of gender diversity on tax avoidance. This study is different from that of Olayinka et al.'s (2016) as it focuses on the listed manufacturing firms using the book tax difference to capture tax avoidance. In addition, it extends prior studies on how gender diversity affects tax avoidance and accounting conservatism, by not only investigating the effect of female CEO and the proportion of women but also the presence of women in the audit committee. Additionally, given the inconclusive findings on the relationship between females in governance and tax avoidance, the moderating role of accounting conservatism on the effect of females in governance on the corporate tax avoidance of listed manufacturing firms in Nigeria is also examined.

\section{Review of Literature and Hypothesis Development}

In contrast to men, women exhibit less opportunism in decision making (Krishnan \& Parsons, 2008). The commonly held view is that: under similar circumstance, a risk-averse individual will opt for the alternative with guaranteed outcome than gamble. Several researchers have attempted to revalidate the assertion that females are less risk loving than males. Conclusions from many of these studies are consistent with the view that females are less risk loving than males.

Based on the 150 studies reviewed from 1967 to 1997, Byrnes, Miller and Schafer (1999) claimed that females are less risk loving than males. Meanwhile, Parrotta and Smith (2013) found that women led firms have lower variability in sales, equity, profits and investments compared to firms 
led by men. Similarly, the evidence provided supports their hypothesis that females are less risk loving than males. In addition, the findings show that women focus more on monitoring and implementing stricter firm governance activities. Berggren and Gonzalez (2010) established that contrary to their male counterparts, women approach financial decisions in a more conservative manner. The female risk aversion theory is therefore well rooted in the field of psychology and organisational literature (Francis et al., 2014).

Kasipillai and Abdul Jabbar (2006) examined whether ethnicity and gender differences affects tax compliance attitude and behavior. Deviating from earlier studies, data was sourced from primary sources through the interview with taxpayers in urban towns. Based on the t-test analysis, the tax compliant attitude between women and men are found to be similar. Contrary to their expectation, the results showed that gender is statistically significant and a determinant of non-compliance attitude. It was concluded that gender of the tax returns preparer influences compliance attitude.

Richardson, Taylorand Lanis (2015) investigated the nexus between female directors and tax avoidance using Australia firms. The sample was made up of 205 firms from 2006 to 2010. Deviating from other studies, tax aggressiveness was proxied using dummy variable equal to one if the company is a party to a tax dispute and zero otherwise. The study adopted multivariate regression analysis in examining this relationship. The study controlled several variables; the board independence, average directors age, external directorship, CEO tenure, duality, big four audit, level of stockholding, executive compensation and firm size. Consistent with their expectation that female directors improve ethical standards, communication and effective oversight functions, it was found that female directors in the boardroom reduce tax aggressiveness. The researchers provided robust result which is consistent with the alternative measures of tax aggressiveness.

Boots (2015) investigated whether tax aggressiveness is influenced by female representation in the top management. The empirical analysis based on 20,068 firm-year observations showed a negative effect of female management representation on corporate tax avoidance for firms with one female representation. Contrary to prior studies, the inverse relationship is more negative for companies operating in the retail industry contrary to other industries. The findings suggest that although risk tolerant women self-select into top managerial positions, they are not equal to their male counterparts in terms of risk taking.

Using the premise Stakeholders theory, Streefland (2016) investigated whether female board participation improves the bottom line performance 
of companies through tax avoidance. They focused on the the United States publicly traded firms between 2009 and 2014. Uncertain tax benefit positions (UTB) and GAAP effective tax rates was utilised as primary measures of tax avoidance. Using the Ordinary Least Squares regression, it was found that female executives affect corporate tax avoidance. The study further tested the moderating impact of shareholder rights. The results showed significant effect of women directors on uncertain tax benefit positions but insignificant impact on GAAP effective tax rates. The evidence revealedthat the impact of female directorship on GAAP effective tax rates decline in the presence of strong shareholder rights in a company. The sign of direction of UTB and the GAAP ETR in relation to corporate tax avoidance was conflicting.

Olayinka et al (2016) examined the effect of gender diversity on tax aggressiveness using banks quoted on the Nigerian Stock Exchange. The study utilised cross sectional time-series research design. The result showed an insignificant association effect of female directors on tax aggressiveness. Furthermore, the moderating effect of board size significantly reduces tax aggressiveness. However, the study utilized only the ration of female directors in testing the gender effect.

Novita (2016) investigated the relationship between the gender of executives and tax avoidance. Gender is proxied as a dummy variable equal to one if there is female presence on the board and zero otherwise while cash effective tax rate is used to capture tax avoidance. The study utilised data from the firms quoted on Indonesia Stock Exchange from 2009 to 2014 and regression technique for testing the hypothesis. It was found that male directors were more courageous in taking tax avoidance risk when compared to the female directors. The study did not distinguish between CEO and CFO and could therefore not establish their individual effects.

Based on the argument that tax avoidance is part of a company's capital management strategies, Rahimipour (2017) examined the impact of women's representation and participation on the board of directors on tax avoidance among quoted companies on the Tehran Stock Exchange. Data was collected during the period 2010 to 2015 . The panel regression was carried out using data compilation method with the approach of combined effects. The tax avoidance was measured using the effective tax rates. The finding was in line with apriori expectation which showed that female directorship and tax avoidance are negatively related. It was concluded that corporate board gender diversity leads to more extensive supervisions. Furthermore, female directors are not risk loving and have high ethical standards. We therefore hypothesise as follows: 
$\mathrm{H}_{1}$ : $\quad$ Female CEO does not have significant positive effect on tax avoidance among listed manufacturing firms in Nigeria.

$\mathrm{H}_{2}$ : The proportion of female directors does not have significant positive effect on tax avoidance among listed manufacturing firms in Nigeria.

$\mathrm{H}_{3}$ : The presence of a female in the audit committee does not have significant positive effect on tax avoidance among listed manufacturing firms in Nigeria.

This study argues that the firms' tax position is affected by their financial accounting choices. In anticipation of the Inland Revenue acceptance of a tax treatment, the management may choose financial accounting method that increases tax savings and cash flows. Prior studies have shown evidence on the nexus between the corporate tax avoidance and accounting conservatism. Kelly (2005) examined whether taxes affect conservatism in financial reporting. In line with taxes being a determinant of conservatism in financial reporting, they predict that companies with large differences between preconservative book income and taxable income are the most conservative and they are less conservative after the tax change. By excluding the financial firms and companies with foreign incorporation, the study utilised a sample of 30,189 observations from the Compustat Annual Industrial Research files during the period 1991 to 2004 . The result is consistent with taxes being a determinant of conservatism in financial reporting among the United States (US) firms. In addition, the evidence reveals that the firms are less conservative after the exogenous change in the tax rates occured.

Qiang (2007) examined whether the proposed tax explanation for conservatism in the financial reporting applies to both the conditional and unconditional accounting conservatism. Data was extracted from the Compustat from 1982 to 2002. By utilising the cross sectional regressions and after controlling for the conditional accounting conservatism, it was found that taxation induces unconditional conservatism. This implies that the firms pushing for reduction in corporate tax applies unconditional accounting conservatism in the financial reporting in deferring tax liabilities. Additional analysis revealed that both conditional and unconditional accounting conservatisms are exclusively dependent. However, in solving endogeneity problems, the study adopted a parsimonious approach instead of the simultaneous equation analysis.

Kim and Jung (2007) examined the nexus between accounting conservatism and corporate taxation. They argued that accounting conservatism is a vital tool in tax minimisation strategies. The study applied multiple regressions as 
a tool of analysis using a sample of 2,251 firm years from 1997 to 2002. It was found that unconditional conservatism in the financial reporting is driven by the corporate taxation. However, no significant relationship was found between the corporate taxation and conditional accounting conservatism. Further analysis revealed that the non-tax costs and the extent of book tax conformity affects the tax driven conservatism. That is, the lower book tax difference improves the relationship between accounting conservatism and corporate tax.

Garcia et al. (2005) examined the determinants of accounting conservatism. Contrary to prior studies, the corporate tax was measured using the firm year level tax pressures and book tax conformity. A sample of 93,838 firmyear observations was extracted from the Compustat covering the period from 1964 to 2005. By utilizing regression as tool of analysis, they found that corporate taxation induced both the conditional and unconditional accounting conservatism. That is, the taxation provides the firm incentives to shift earnings from high tax pressure periods to lower tax pressure periods. In the presence of adequate management incentives, this is achieved through recognising economic losses in the current period that would otherwise have been shifted to future periods. Also, the economic gains are deferred into the future periods that would otherwise have been recognised in the current period.

Mariem, Trabelsi and Matoussi (2012) compared accounting conservatism in the US high-tech firms andlow-technology firms. They further examined the factors contributing to their conservative accounting practice. Furthermore, they argued that the lower level of conditional conservatism in high-tech firms was not driven by their taxable earnings. Data was obtained from the Compustat from 1974 to 2010 comprising 16,396 firm-years. The results showed that the firms practiced conservative accounting practice. Consistent with the notion that taxation induces only unconditional accounting conservatism, the evidence revealed that the taxation does not drive conditional accounting conservatism. This implies that only unconditional accounting conservatism is employed by the managers in the deferment of corporate tax.

In response to China new enterprise tax law in 2008, Jin and Cheng (2013) investigated the relationship between the tax costs and accounting conservatism. They tested the postulation of Watts (2003) that conservatism in financial reporting was driven by taxation. Data was obtained from China's A-share listed company through Shanghai and Shenzhen stock exchange. It was found that accounting conservatism is significantly related to companies' tax burden. This indicates that the more the firm tax was 
burdened, the willingness to employ conservative financial reporting would be higher. Further analysis revealed that this relationship is high for firms owned by the state. In addition, the nature of enterprise equity was found to be an important factor in tax motivated conservative reporting.

Based on the proposition that accounting conservatism is considered one of firm's policies regarded as tax incentives, Seyyedi (2014) attempted to find out strategies used by quoted firms in Tehran Stock Exchange to reduce their corporate tax. The study examined the effect of accounting conservatism on tax avoidance using 146 firms (1177 firm-years) quoted on Tehran Stock Exchange within the period 2002 to 2012. The study employed ordinary least square regression technique on an unbalanced panel data. The result showed a significant negative effect of tax avoidance on accounting conservatism. The evidence revealed that companies tend to adopt the accounting conservatism and decrease the profit for tax savings.

Christensen, Dhaliwal, Boivie, and Graffin, (2014) extended the upper echelon studies by investigating the effects of top management conservatism on the corporate risk strategies using data from ExecuComp database for the years 1992-2008. Management conservatism was proxied by management political orientation and the corporate risk strategies were measured by tax avoidance. The analysis based on ordinary least square and ordered logistic regression was conducted. It was found that the management conservatism is important in explaining corporate tax avoidance especially when managers are entrenched.

$\mathrm{H}_{4}$ : Accounting conservatism does not significantly moderate the effect of Female CEO on tax avoidance among listed manufacturing firms in Nigeria.

$\mathrm{H}_{5}$ : Accounting conservatism does not significantly moderate the effect of proportion of female directors on tax avoidance among listed manufacturing firms in Nigeria.

$\mathrm{H}_{6}$ : Accounting conservatism does not significantly moderate the effect of female presence in the audit committee on tax avoidance among listed manufacturing firms in Nigeria.

\section{Methodology}

The paradigm for this study is positivism which allows quantitative and deductive frameworks in testing hypothesis. The framework is quantitative 
involving formal and systematic measurement and use of statistical technique to obtain findings. This study therefore utilised ex-post factor research design as it entails determining the relationship between two more variables. This design is consistent with the previous studies on female directors and corporate tax conducted by Streefland (2016) and Richardson et al. (2015). The study employed Panel corrected standard regressions technique.

The population comprised all manufacturing companied quoted on the Nigerian stock exchange as at December $31^{\mathrm{t}}, 2018$. According to the NSE classification, these firms are under conglomerates subsectors, health care, industrial goods and consumer goods. The number of firms under these sub sectors is 58 firms. Table 1 shows the process of attaining the sample and the spread of firms in the sample per sub sector.

Table 1

Sample Procedure

\begin{tabular}{lccc}
\hline Panel A & & & \\
\hline Sub-sector & $\begin{array}{c}\text { Number of of } \\
\text { firms }\end{array}$ & $\begin{array}{c}\text { Firm-year } \\
\text { observation }\end{array}$ & \\
\hline Initial population & 58 & 348 & \\
Missing data (-) & 37 & 222 & \\
Final sample & 21 & 126 & of total \\
\hline Panel B & & & 14.29 \\
\hline Sub-sector & Number of & Firm-year \\
& firms & 18 & 23.81 \\
\hline Conglomerates & 3 & 30 & 19.04 \\
Industrial goods & 5 & 24 & 42.86 \\
Health Care & 4 & 54 & 100 \\
Consumer goods & 9 & 126 & \\
\hline Total & 21 & &
\end{tabular}

A general condition must be satisfied for a variable to be used as a moderating variable. It must have an impact on the dependent variable. In addition, all the independent variables must have a significant impact on the moderating variable. Therefore, the conditional models for utilising accounting conservatism as a moderating variable are stated thus: 


$$
\begin{aligned}
& \text { TBTD }_{i t}=\alpha_{0}+\beta_{1} \text { CONACC }_{i t}+\beta_{2} F S_{i t}+\beta_{3} L E V_{i t}+\beta_{4} B S_{i}+\varepsilon_{i} \\
& \text { CONACC }_{i t}=\alpha_{0}+\beta_{1} F C E O_{i t}+\beta_{2} F S_{i t}+\beta_{3} L E V_{i t}+\beta_{4} B S_{i}+\varepsilon_{i t} \\
& \text { CONACC }_{i t}=\alpha_{0}+\beta_{1} F E M_{i t}+\beta_{2} F S_{i t}+\beta_{3} L E V_{i t}+\beta_{4} B S_{i}+\varepsilon_{i t} \\
& \text { CONACC }_{i t}=\alpha_{0}+\beta_{1} F D A D_{i t}+\beta_{2} F S_{i t}+\beta_{3} L E V_{i t}+\beta_{4} B S_{i}+\varepsilon_{i t}
\end{aligned}
$$

Where all the above conditions are satisfied, the study can therefore proceed with other models for testing the hypothesis.

Hypothesis 1

$$
\begin{aligned}
T_{B T D}= & \alpha_{0}+\beta_{1} F C E O_{i t}+\beta_{2} F S_{i t}+\beta_{3} L E V_{i t}+\beta_{4} B S_{i}+\varepsilon_{i t} \\
T B T D_{i t}= & \alpha_{0}+\beta_{1} F C E O_{i t}+\beta_{2} C O N A C C_{i t}+\beta_{3} F S_{i t}+\beta_{4} L E V_{i t}+\beta_{5} B S_{i}+\varepsilon_{i t} \\
T B T D_{i t}= & \alpha_{0}+\beta_{1} F C E O_{i t}+\beta_{2} C O N A C C_{i t}+\beta_{3} F C E O C O N_{i t}+ \\
& \beta_{4} F S_{i t}+\beta_{5} L E V_{i t}+\beta_{6} B S_{i t}+\varepsilon_{i t}
\end{aligned}
$$

Hypothesis 2

$$
\begin{aligned}
T_{B T D}= & \alpha_{0}+\beta_{1} F_{i t}+\beta_{2} F S_{i t}+\beta_{3} L E V_{i t}+\beta_{4} B S_{i}+\varepsilon_{i t} \\
T_{B T D}= & \alpha_{0}+\beta_{1} F E M_{i t}+\beta_{2} \text { CONACC }_{i t}+\beta_{3} F S_{i t}+\beta_{4} L E V_{i t}+\beta_{5} B S_{i}+\varepsilon_{i t} \\
T_{B T D}= & \alpha_{0}+\beta_{1} F E M_{i t}+\beta_{2} \text { CONACC }_{i t}+\beta_{3} \text { FEMCONACC }_{i t}+ \\
& \beta_{4} F S_{i t}+\beta_{5} L E V_{i t}+\beta_{6} B S_{i}+\varepsilon_{i t}
\end{aligned}
$$

Hypothesis 3

$$
\begin{aligned}
\text {TBTD }_{i t}= & \alpha_{0}+\beta_{1} F D A D_{i t}+\beta_{2} F S_{i t}+\beta_{3} L E V_{i t}+\beta_{4} B S_{i}+\varepsilon_{i t} \\
\text { TBTD }_{i t}= & \alpha_{0}+\beta_{1} F D A D_{i t}+\beta_{2} \text { CONACC }_{i t}+\beta_{3} F S_{i t}+\beta_{4} L E V_{i t}+\beta_{5} B S_{i}+\varepsilon_{i t} \\
\text { TBTD }_{i t}= & \alpha_{0}+\beta_{1} F D A D_{i t}+\beta_{2} \text { CONACC }_{i t}+\beta_{3} F D A D C O N A C C_{i t}+\beta_{4} F S_{i t}+ \\
& \beta_{5} L E V_{i t}+\beta_{6} B S_{i}+\varepsilon_{i t}
\end{aligned}
$$

where: TBTD= Total book tax difference

CONACC = Accounting conservatism

FEMCEO = Female CEO

FEM = Proportion of female directors on the board 


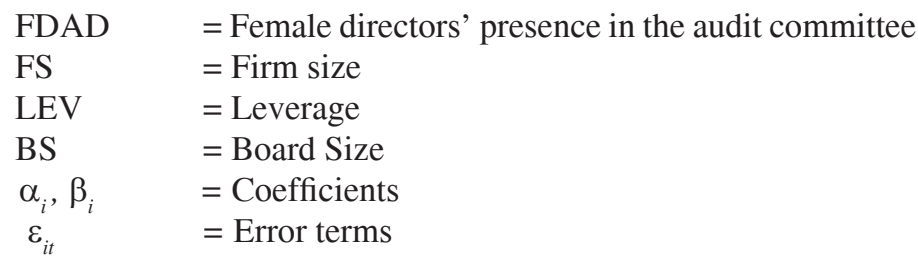

The symbols $\alpha, i, t$ and $\varepsilon_{i t}$ denote the constant term, company, year and disturbance error term of the model. The models 1a, 2a and 3a attempt to estimate the direct effect of the independent variables on the dependent variables. Where there exists a direct effect of female presence in the governance on tax avoidance, the next step is the nexus between the independent variables and the moderating variable captured by model $1 \mathrm{~b}, 2 \mathrm{~b}$ and $3 \mathrm{~b}$. The mediating impact is captured by model $1 \mathrm{c}, 2 \mathrm{c}$ and $3 \mathrm{c}$. Finally, the moderating effect is captured by $\beta_{3}$ in models $1 \mathrm{~d}, 2 \mathrm{~d}$ and $3 \mathrm{~d}$. This represents the interaction between accounting conservatism and the three independent variables and their effects on tax avoidance. They depict the moderating effect of accounting conservatism on the relationship between females in the governance and tax avoidance. The table below shows the measurement of variables

Table 2

Definitions and Measurements of the Variables

\begin{tabular}{lll}
\hline Variables & Measurement & Source \\
\hline Tax avoidance & Total Book Tax Difference & $\begin{array}{l}\text { Chyz, Gaertner, Kausar } \\
\text { and Watson (2015) }\end{array}$ \\
$\begin{array}{l}\text { Accounting } \\
\text { Conservatism }\end{array}$ & Negative Accruals and Hayn (2000) \\
Female CEO & $\begin{array}{l}\text { Measured as a dummy variable equal } \\
\text { to } 1 \text { if the CEO is a female and zero } \\
\text { otherwise }\end{array}$ & $\begin{array}{l}\text { Ho, Li, Tam, and Zhang } \\
\text { (2014). }\end{array}$ \\
$\begin{array}{l}\text { Percentage } \\
\text { of female }\end{array}$ & $\begin{array}{l}\text { Measured as the percentage of females } \\
\text { on thectors } \\
\text { directors to the total number of }\end{array}$ & Khaoula and Ali (2012) \\
$\begin{array}{l}\text { Presence of } \\
\text { Female director } \\
\text { in the Audit } \\
\text { Committee }\end{array}$ & $\begin{array}{l}\text { Measured as a dummy variable equal } \\
\text { to } 1 \text { if there is a female director in the }\end{array}$ & \\
Firm Size & Log of total assets & \\
Leverage & Total liabilities to total assets & Katz, Khan and Schmidt \\
Board Size & Log of Board Size & \\
\hline
\end{tabular}




\section{Results and Discussion}

This sub section gives the features of the data. Primarily, the mean, minimum, maximum and standard deviation of the data are discussed below.

Table 3

\section{Descriptive Statistics}

\begin{tabular}{llllllll}
\hline Variable & $\mathrm{N}$ & Mean & Std Dev. & Min & Max & Skewness & Kurtosis \\
\hline TBTD & 126 & -0.0655 & 0.1280 & -0.6010 & 0.2957 & -2.2760 & 11.7302 \\
FCEO & 126 & 0.0714 & 0.2585 & 0 & 1 & 3.3282 & 12.0769 \\
FEM & 126 & 0.0936 & 0.1043 & 0 & 0.3333 & 0.7281 & 2.3098 \\
FDAD & 126 & 0.2698 & 0.4456 & 0 & 1 & 0.3215 & 1.1033 \\
CONACC & 126 & -0.0528 & 0.1011 & -0.4910 & 0.2471 & -0.6870 & 7.7673 \\
LTA & 126 & 7.5116 & 0.7306 & 5.6260 & 9.0509 & -0.5257 & 3.1652 \\
LEVTA & 126 & 0.5177 & 0.2754 & 0.1830 & 2.4882 & 3.7601 & 24.5913 \\
LBS & 126 & 0.9719 & 0.1076 & 0.7781 & 1.2552 & 0.1418 & 2.6145 \\
\hline
\end{tabular}

On the average, the firms in our sample reported negative TBTD of -0.0065 during the period 2013-2018. Although the sample firms do not exhibit tax avoidance practice, firms reported differences in taxable income compared to accounting income. The standard deviation of 0.1280 relative to the mean of -0.0065 indicate significant differences in tax avoidance across firms. While the minimum TBTD is -0.6010 , the maximum depicts a value of 0.2957 . The skewness and Kurtosis figures of -2.2760 and 11.7302 give an indication of non-normality. Given that the study utilises real data, tehe ormality assumption is likely to be untrue.

The presence of female CEO is still generally rare in practice in Nigeria listed manufacturing firms. However, the maximum value of 1 show few firms have female CEOs within the period of the study. The mean value for female CEO is 0.0714 indicating that on the average, 7.14 percent of the sample firms have female CEOs during period of the study. This suggests that the barrier to having female leadership still exist within Nigerian listed firms. This is similar with what is obtainable even in the US as reported by Palvia, Vähämaa and Vähämaa (2014) which comprised prior studies (e.g., Krishnan \& Parsons, 2008). Being a dummy variable measure, the values for the skewness and kurtosis of 3.3282 and 12.0769 indicating non normality is not surprising. 
The mean value for the proportion of female directors on the board is 0.0936 suggesting that on the average, 9.36 percent of directors on the board of Nigerian manufacturing firms are females. The percentage is also lower than the mean for Finnish firms as found by Wang (2015). There are some firms with no female directors as indicated by the minimum values of 0 . The percentage of female directors on the board never exceeded 33 percent as indicated by maximum value of 0.3333 . This is not a surprise as some of the firms lack presence of female either as executive or non-executive director. However, the skewness and kurtosis of 0.7281 and 2.3098 indicates slight non normality of the variable.

Contrary to other proxies for females in governance, the female directors in the audit committee have a mean value of 0.268 . This indicates that on the average, 26.98 percent of Nigeria listed non-financial firms have females in their audit committee. Deductively, 73.02 percent of these firms have no female representation in their audit committee during the period. Furthermore, the firm years with female presence in the audit committee are 33 out of 126. This is higher compared to Malaysian listed firms of only 17 percentas reported by Ismail and Abdullah (2013). The skewness and kurtosis values of 0.3215 and 1.1033 suggest a minimum deviation from normality.

The mean value of our CONACC is -0.0528 which implies the low level of accounting conservatism for the period. This is lower to the level of accrual accounting conservatism as reported by Francis et al. (2014). This not surprising, as recent pronouncement of by IASB limits the extent of accounting conservatism in financial reporting. However, the values for skewness and kurtosis of -0.6870 and 7.7673 indicate significant variations in accounting practice across sample firms within the period. The minimum value for conservative reporting is -0.4919 while the maximum shows a figure of 0.2471 .

On the average, the size of Nigerian manufacturing firms is 7.5116. In terms of leverage, the average ratio of debt to total assets is 51.77 percent during the period. The minimum is 18.3 percentwhile the maximum is 248.8 percent of total assets. In relation to board size, the mean value is 0.9719 (9.63) indicating an average board size of 9 for Nigerian manufacturing firms. The minimum board size is 0.7781 (6) while the largest board size of 1.2552 (18). However, it is noteworthy that no firm exceeded the maximum of twenty (20). In the following, we shall look at the correlation between the proxies for females in the governance, tax avoidance and among the regressors themselves. This gives a-priori information possible on multicollinearity and the direction of perceived relationships. 
Table 4 reports Pearson correlations among the main variables of interest. While female CEO is inversely associated with tax avoidance, the percentage of female directors on the board and female director presence on the audit committee are positively associated with tax avoidance. The moderating variable, accounting conservatism is negatively associated with tax avoidance. Apart from the board size, all the control variables have significant effect on tax avoidance. However, while firm size and board size are positive, the leverage is negatively related with the tax avoidance. The correlation coefficients do not suggest the presence of multicollinearity among the variables. The highest correlation coefficient is 54.8 percent which is between board size and firm size.

Table 4

Correlation Matrix

\begin{tabular}{|c|c|c|c|c|c|c|c|c|c|}
\hline & TBTD & FCEO & FEM & FAD & $\mathrm{CON}$ & PROF & TA & LTA & BS \\
\hline TBTD & 1.000 & & & & & & & & \\
\hline FCEO & -0.0284 & 1.000 & & & & & & & \\
\hline FEM & 0.1335 & 0.463 & 1.000 & & & & & & \\
\hline FDAD & 0.1399 & 0.2480 & 0.5351 & 1.000 & & & & & \\
\hline $\mathrm{CON}$ & -0.352 & -0.168 & -0.181 & -0.223 & 1.000 & & & & \\
\hline PROF & 0.497 & 0.461 & 0.438 & 0.263 & -0.567 & 1.000 & & & \\
\hline TA & 0.517 & -0.488 & -0.0647 & 0.1109 & -0.0798 & 0.198 & 1.000 & & \\
\hline LVTA & -0.540 & -0.056 & -0.1410 & 0.0554 & 0.412 & -0.265 & -0.0910 & 1.00 & \\
\hline BS & 0.0748 & -0.404 & -0.0606 & 0.0284 & 0.1171 & -0.1460 & 0.548 & 0.066 & 1.0 \\
\hline
\end{tabular}

Table 5 shows the ordinary least square regression together with the BreuschPagan test for heteroskedasticity. The Chi Square values from 54.74 to 66.87 which are all significant at 1 percent. This indicates that all the models suffer from heterokedasticity problems. Consequently, the regression above could not use in the rejection or otherwise of the hypothesis. However, the adjusted $\mathrm{R}^{2}$ figures provide evidence for moderation. The model for female CEO increased from 56.30 to 58.64 while the percentage of female directors on the board increased from 54.14 to 57.76 . The final moderation which relates to the presence of female directors in the audit committee increased from 54.26 to 57.03 .

Although, coefficients from the correlation matrix table suggest absence of multicollinearity among the variable given that none of the coefficients is up to 0.70 , it is better to apply a more robust technique of testing for multicollinearity among variables. 
Table 5

Test of Heteroskadisticity

\begin{tabular}{|c|c|c|c|c|c|c|}
\hline Variable & Model 1 & Model 2 & Model 3 & Model 4 & Model 5 & Model 6 \\
\hline FCEO & $0.0998 * * *$ & & & $0.1339 * * *$ & & \\
\hline FEM & & 0.1160 & & & $0.2035^{* *}$ & \\
\hline FDAD & & & 0.0287 & & & 0.0348 \\
\hline CONACC & & & & $-0.2584 * * *$ & $-0.4697 * * *$ & $-0.3465 * * *$ \\
\hline CEOCON & & & & 0.4422 & & \\
\hline FEMCON & & & & & $1.9021 * *$ & \\
\hline FDADCO & & & & & & 0.2729 \\
\hline FS & $0.1184^{* * *} *$ & $0.1056^{* * * *}$ & $0.1034 * * *$ & $0.1132 * * *$ & $0.0947 * * *$ & $0.0937 * * *$ \\
\hline LEV & $-0.2119 * * *$ & $-0.2130 * * *$ & $-0.2179 * * *$ & $-0.1711^{* * * *}$ & $-0.1524 * * *$ & $-0.1793 * * *$ \\
\hline LBS & $-0.2190^{* *}$ & $-0.2614 * * *$ & $-0.2483 * * *$ & $-0.1983 * *$ & $-0.2562 * * *$ & $-0.2158 * *$ \\
\hline $\mathrm{R}^{2}$ & 0.5630 & 0.5414 & 0.5426 & 0.5864 & 0.5776 & 0.5703 \\
\hline F.ST & $41.26^{* * *}$ & $37.89 * * *$ & $38.07 * * *$ & $30.53 * * *$ & $29.49 * * *$ & $28.65 * * *$ \\
\hline HETEST & $66.87^{* * *}$ & $58.75^{* * * *}$ & $60.23 * * *$ & $66.54 * * *$ & $55.57 * * *$ & $54.74 * * *$ \\
\hline
\end{tabular}

Table 6

Multicollinearity Test

\begin{tabular}{lcccccc}
\hline Variable & $\begin{array}{c}\text { VIF } \\
\text { Model 1 }\end{array}$ & $\begin{array}{c}\text { VIF } \\
\text { Model 2 }\end{array}$ & $\begin{array}{c}\text { VIF } \\
\text { Model 3 }\end{array}$ & $\begin{array}{c}\text { VIF } \\
\text { Model 4 }\end{array}$ & $\begin{array}{c}\text { VIF } \\
\text { Model 5 }\end{array}$ & $\begin{array}{c}\text { VIF } \\
\text { Model 6 }\end{array}$ \\
\hline FCEO & 1.37 & & & 2.88 & & \\
FEM & & 1.03 & & & 1.84 & \\
FDAD & & & 1.01 & & & 1.69 \\
CONACC & & & & 1.49 & 3.60 & 2.28 \\
CEOCON & & & & 2.73 & & \\
FEMCON & & & & & 4.56 & \\
FDADCO & 1.68 & 1.47 & 1.47 & 1.82 & 1.56 & 1.57 \\
FS & 1.04 & 1.05 & 1.03 & 1.31 & 1.51 & 1.24 \\
LEV & 1.50 & 1.46 & 1.47 & 1.57 & 1.63 & 1.54 \\
LBS & 1.40 & 1.25 & 1.25 & 1.97 & 2.45 & 1.87 \\
MVIF & & & & & & 2.92 \\
\hline Note $* * *$ and $* * *$ denote statistically significance at $10 \%, 5 \%$ and $1 \%$ respectively.
\end{tabular}


Variance inflation factors of more than 10 suggest the presence of multicollinearity among the variables. The result above shows that VIF ranges from 1.01(FDAD) to 4.56 (FEMCON). The variable with the highest VIF is a multiplication of the percentage of female directors and accounting conservatism. This indicates absence of harmful multicollinearity and all variables are retained for analysis.

This study tests the effect of moderating variable on the dependent variable. In addition, the independent variables are tested on the moderating variable as shown in Equation (1) - Equation (4).

$$
\begin{aligned}
& \text { TBTD }_{i t}=\alpha_{0}+\beta_{1} \text { CONACC }_{i t}+\beta_{2} F S_{i t}+\beta_{3} L E V_{i t}+\beta_{4} B S_{i}+\varepsilon_{i} \\
& \text { CONACC }_{i t}=\alpha_{0}+\beta_{1} F C E O_{i t}+\beta_{2} F S_{i t}+\beta_{3} L E V_{i t}+\beta_{4} B S_{i}+\varepsilon_{i t} \\
& \text { CONACC }_{i t}=\alpha_{0}+\beta_{1} \text { FEM }_{i t}+\beta_{2} F S_{i t}+\beta_{3} L E V_{i t}+\beta_{4} B S_{i}+\varepsilon_{i t} \\
& \text { CONACC }_{i t}=\alpha_{0}+\beta_{1} F D A D_{i t}+\beta_{2} F S_{i t}+\beta_{3} L E V_{i t}+\beta_{4} B S_{i}+\varepsilon_{i t}
\end{aligned}
$$

Table 7 shows the result for the conditional models. As first condition, the moderating variable, accounting conservatism has a significant negative effect on tax avoidance. This is contrary to a-priori expectation that accounting conservatism increases tax avoidance. Also, this is not in line with positive accounting theory as postulated by Watts (2003) that accounting conservatism is used to defer tax payments into the future. This, however, suggests that accounting conservatism reduces tax avoidance practices, which is desirable. The overall explanatory power of the model is 58 percent, while the F. Statistics shows a value of 60.93 which is significant at 1 percent.

The second condition is that all the independent variables must have significant effect on the moderating variable when used as the dependent variable. The result above shows all the independent variables have significant effects on the accounting conservatism. Interestingly, all the independent variables have negative significant effects on accounting conservatism. This implies female representation on the board reduces the conservative accounting practice. Given that accounting conservatism decreases earnings management, more females on the board suggest higher earnings management. The three models have $\mathrm{R}^{2}$ values of $0.2394,0.2281$ and 0.2680 , and F. Values of 38.38, 37.29 and 36.48 which are all fit at 1 percent level of significance. 
Table 7

\section{Conditional Models}

\begin{tabular}{|c|c|c|c|c|}
\hline \multicolumn{2}{|c|}{ TBTD as Dependent Variable } & \multicolumn{3}{|c|}{ CONACC as Dependent Variable } \\
\hline Variable & Model (i) & Model (ii) & Model (iii) & Model (iv) \\
\hline CONACC & $-0.2552 * * *$ & & & \\
\hline FCEO & & $-0.0952 * *$ & & \\
\hline FEM & & & $-0.1753 * *$ & \\
\hline FDAD & & & & $-0.0611 * * *$ \\
\hline FS & $0.0978 * * *$ & $-0.3916^{* * *}$ & $-0.2756 * *$ & $-0.2351 * *$ \\
\hline LEV & $-0.1854 * * *$ & $0.1259^{* * *}$ & $0.1233^{* * *}$ & $0.1298 * * *$ \\
\hline BS & $-0.2071 * * *$ & $0.1763^{* *}$ & $0.2160 * * *$ & $0.1873^{* *}$ \\
\hline $\mathrm{R}^{2}$ & 0.5800 & 0.2394 & 0.2281 & 0.2680 \\
\hline F.Statistics & $60.93 * * *$ & $38.38 * * *$ & $37.29 * * *$ & $36.48 * * *$ \\
\hline
\end{tabular}

Note: $* * *$ and $* * *$ denote statistically significance at $10 \%, 5 \%$ and $1 \%$ respectively.

\section{Female Representation and Tax Avoidance}

Table 8 shows the regression of tax avoidance on the different proxies of female representation on the board. It only depicts the direct effect of females in governance on tax avoidance practices.

$$
\begin{aligned}
& \text { TBTD }_{i t}=\alpha_{0}+\beta_{1} F_{1} C E O_{i t}+\beta_{2} F S_{i t}+\beta_{3} L E V_{i t}+\beta_{4} B S_{i}+\varepsilon_{i t} \\
& T_{B T D}=\alpha_{0}+\beta_{1} F E M_{i t} \beta_{2} F S_{i t}+\beta_{3} L E V_{i t}+\beta_{4} B S_{i}+\varepsilon_{i t} \\
& T_{\text {TBTD }}=\alpha_{i t}+\beta_{1} F D A D_{i t}+\beta_{2} F S_{i t}+\beta_{3} L E V_{i t}+\beta_{4} B S_{i}+\varepsilon_{i t}
\end{aligned}
$$

Table 8

Direct Effect of Females in Governance on Tax Avoidance

\begin{tabular}{lccc}
\hline Variables & Model 1a & Model 2a & Model 3a \\
\hline FCEO & $0.0998^{* *}$ & & \\
FEM & & $0.1160^{*}$ & $0.0287^{*}$ \\
FDAD & & $0.1056^{* * *}$ & $0.1034^{* * *}$ \\
FS & $0.1184 * * *$ & $-0.2130^{* * *}$ & $-0.2179 * * *$ \\
LEV & $-0.2119^{* * *}$ & $-0.2614^{* * *}$ & $-0.2483 * * *$ \\
BS & $-0.2190^{* * *}$ & 0.5561 & 0.5573 \\
R & 0.5770 & $54.85^{* * *}$ & $54.42 * * *$ \\
F. Statistics & $60.46^{* * *}$ & &
\end{tabular}


Table 8 shows the direct effect of females in governance on tax avoidance practice in listed manufacturing firms in Nigeria. The three models show explanatory power of $0.5770,0.5561$ and 0.5573 respectively. This suggests that explanatory variables account for at least 50 percent variation in tax avoidance practices across firms. The three models indicate F.Statistics of $60.46,54.85$ and 54.42 which are all significant at 1 percent. Interestingly, the three proxies for females in the governance show a positive significant effect on tax avoidance across models. The consistency of results across all the models suggests that female directors increase tax savings for the firms. In whichever position, the female directors tend to favour lowering tax liabilities of the firms.

\section{The Mediating Effect of Accounting Conservatism}

Table 9 shows the mediating effect of accounting conservatism on the relationship between female directors and tax avoidance. The mediating effect is captured by the inclusion of accounting conservatism in the models.

$$
\begin{aligned}
& \text {TBTD }_{i t}=\alpha_{0}+\beta_{1} F C E O_{i t}+\beta_{2} \text { CONACC }_{i t}+\beta_{3} F S_{i t}+\beta_{4} L E V_{i t}+\beta_{5} B S_{i}+\varepsilon_{i t} \\
& T B T D_{i t}=\alpha_{0}+\beta_{1} F E M_{i t}+\beta_{2} C O N A C C_{i t}+\beta_{3} F S_{i t}+\beta_{4} L E V_{i t}+\beta_{5} B S_{i}+\varepsilon_{i t} \\
& \text { TBTD }_{i t}=\alpha_{0}+\beta_{1} F D A D_{i t}+\beta_{2} \text { CONACC }_{i t}+\beta_{3} F S_{i t}+\beta_{4} L E V_{i t}+\beta_{5} B S_{i}+\varepsilon_{i t}
\end{aligned}
$$

\begin{tabular}{|c|c|c|c|}
\hline Variables & Models 1b & Models 2b & Models $3 \mathrm{~b}$ \\
\hline FCEO, & $0.0798 *$ & & \\
\hline FEM & & 0.0742 & \\
\hline FADAD & & & 0.0144 \\
\hline CONACC & $-0.2101 * *$ & $-0.2384 * * *$ & $-0.2341 * * *$ \\
\hline FS & $0.1102 * * *$ & $0.0990 * * *$ & $0.0978 * * *$ \\
\hline LEV & $-0.1854 * * *$ & $-0.1836 * * *$ & $-0.1875 * * *$ \\
\hline BS & $-0.1819 * *$ & $-0.2099 * * *$ & $-0.2044 * * *$ \\
\hline $\mathrm{R}^{2}$ & 0.5979 & 0.5834 & 0.5823 \\
\hline F. Statistics & $66.74 * * *$ & $61.65^{* * *}$ & $61.37 * * *$ \\
\hline
\end{tabular}

Table 9

\section{Mediating Effect of Accounting Conservatism}


The mediating effect is determined by the change in the effect of the independent variable on the dependent variable as a result of the introduction of the mediation variable. Where the effect of the independent variable changes from significant to insignificant, there is a complete mediation. However, where the effect of the independent variable on the dependent variable remains significant in the presence of the mediating variable, there is a partial mediation. The result above shows that accounting conservatism partially mediated the relationship between female CEO and tax avoidance. This is due to the drop in the level of significance from 5 percent to 10 percent. With regards to the percentage of female directors on the board and female director presence on the audit committee, there is a complete mediation. This is indicated by the insignificant effect of female directors on the board and the female director presence on the audit committee on tax avoidance in the presence of accounting conservatism. The explanatory powers of the three models are $0.5979,0.5834$ and 0.5823 respectively which are adequate and are fit at one percent level of significance.

\section{The Moderating Effect of Accounting Conservatism}

Table 10 shows the moderating effect of accounting conservatism on the relationship between female directors and tax avoidance. The moderating effect is captured by the inclusion of a moderating variable across the models.

$$
\begin{aligned}
\text { TBTD }_{i t}= & \alpha_{0}+\beta_{1} F C E O_{i t}+\beta_{2} \text { CONACC }_{i t}+\beta_{3} \text { FCEOCON }_{i t}+\beta_{4} F S_{i t}+ \\
& \beta_{5} L E V_{i t}+\beta_{6} B S_{i t}+\varepsilon_{i t} \\
\text { TBTD }_{i t}= & \alpha_{0}+\beta_{1} F E M_{i t}+\beta_{2} \text { CONACC }_{i t}+\beta_{3} F E M C O N A C C_{i t}+\beta_{4} F S_{i t} \\
& +\beta_{5} L E V_{i t}+\beta_{6} B S_{i}+\varepsilon_{i t} \\
\text { TBTD }_{i t}= & \alpha_{0}+\beta_{1} F D A D_{i t}+\beta_{2} \text { CONACC }_{i t}+\beta_{3} F D A D C O N A C C_{i t} \\
& +\beta_{4} F S_{i t}+\beta_{5} L E V_{i t}+\beta_{6} B S_{i}+\varepsilon_{i t}
\end{aligned}
$$

The moderating effect is determined by the multiplication of each independent variable by the moderating variable. The three models show strong explanatory power of above 50 percent respectively and are all fit at one percent significant level.

\section{Test of Hypotheses}

This section focuses on the acceptability of the hypotheses raised or otherwise. Models 1a, 2a, 3a and1c, 2c 3c are used in testing the hypotheses of the study. 
Table 10

Moderating Effect of Accounting Conservatism

\begin{tabular}{|c|c|c|c|}
\hline Variables & $\begin{array}{l}\text { Models 1c } \\
\text { (FCEO) }\end{array}$ & $\begin{array}{l}\text { Models 2c } \\
\text { (FEM) }\end{array}$ & $\begin{array}{l}\text { Models 3c } \\
\text { (FDAD) }\end{array}$ \\
\hline FCEO, FEM FADAD & $0.1339^{*}$ & $0.2035^{*}$ & $0.0348 * *$ \\
\hline CONACC & $-0.2584 * * *$ & $-0.4697 * * *$ & $-0.3465 * * *$ \\
\hline FCEO,FEM,FADAD*(CONACC) & 0.4422 & $1.9021 *$ & $0.2729 *$ \\
\hline FS & $0.1132 * * *$ & $0.0947 * * *$ & $0.0937 * * *$ \\
\hline LEV & $-0.1711 * * *$ & $-0.1524 * * *$ & $-0.1793 * * *$ \\
\hline BS & $-01983 * *$ & $-0.2562 * * *$ & $-0.2158 * * *$ \\
\hline $\mathrm{R}^{2}$ & 0.6062 & 0.5979 & 0.5909 \\
\hline F.Statistics & $72.80 * * *$ & $69.75^{* * *}$ & $64.17 * * *$ \\
\hline
\end{tabular}

\section{Female CEO and Tax Avoidance}

The result showed that female CEO has significant effect on tax avoidance. Contrary to a-priori expectation, the coefficient for female CEO is significantly positive. This not only suggests that firms having female CEO increases tax savings generated by firms but also higher cash flow available for re-distribution or re-investment which increases firms' net worth. This is contrary to the proposition of tokenism theory which states that the minorities on the board have insignificant effect on the corporate accounting outcomes. However, this is consistent with resource dependency theory which suggests that more valuable resources are provided by diverse boards which have impact on various performance metrics. Although beneficial to shareholders, evidence provided is also consistent with the agency theory as female CEOs may extend tax avoidance to its limits which leads to tax aggressiveness and evasion in the presence of management compensation being tied to performance. The result is also contrary to practical expectation that females are expected to be risk-averse. Therefore, the first hypothesis is rejected. Our findings are contrary to that of Khaoula and Ali's (2012), Francis et al.'s (2014) and Olayinka et al.'s (2016).

\section{Proportion of Female Directors and Tax Avoidance}

With regards to the proportion of female directors on the board, it has a significant effect on tax avoidance. Contrary to a-priori expectation, the 
coefficient for proportion of female directors on the board is significantly positive. The result suggests that tax avoidance increases with the increase in the proportion of female directors on the board. This implies that savings generated by the firms may be higher for firms with more female directors sitting on the board. This finding is contrary to the proposition of tokenism theory which states minorities on the board have insignificant effect on corporate accounting outcomes. Rather, the result is consistent with the resource dependency theory which suggests that more valuable resources are provided by diverse boards which have impact on various performance metrics.

Furthermore, the evidence is also consistent with the agency theory as female directors on the board may extend tax avoidance above the bar resulting in penalties to the firm. The evidence is inconsistent with the practical expectation that female are risk-averse and will not undertake risky accounting choices. Therefore, the second hypothesis is rejected. The finding is contrary to the findings of Khaoula and Ali (2012), Boussaidi and Hamed (2015), Olayinka et al. (2016) and is in support of the findings provided by Yang and Kelton (2015). This finding is contrary to the evidence provided by Adhikari, Agrawal and Malm (2015) that female executives on the board reduce corporate litigation as extreme tax avoidance (aggressiveness) can lead to corporate litigation. However, the evidence provided by this study is consistent with the finding of Boots (2015).

\section{Presence of a Female Director in the Audit Committee and Tax Avoidance}

In relation to the female director presence in the audit committee, it significantly affects tax avoidance. Contrary to a-priori expectation, the coefficient for female director presence in audit committee is positive. This suggests that the presence of female directors in the audit committee reduces firms' cash outflow in the form of tax cost. This finding is contrary to the proposition of tokenism theory which states minorities on the board have insignificant effect on the corporate accounting outcomes. However, the finding is consistent with the resource dependency theory which suggests that diversity presents more valuable resources which has impact on tax avoidance. In the same vein, evidence provided is also consistent with the agency theory as female directors in the audit committee may exceed the limits, giving rise to sanctions. The result is also inconsistent with practical expectation that females are risk-averse and will not impact risky accounting choices. Based on this, hypothesis three is rejected. 


\section{Female CEO and Tax Avoidance: The Moderating Role of Accounting Conservatism}

Contrary to a-priori expectation, the coefficient of FCEOCON has a positive insignificant effect on tax avoidance. This suggests that accounting conservatism does not significantly moderate the effect of female CEO on tax avoidance. This also implies that female CEO does not significantly affect tax avoidance in the firms with conservative accounting practice. Although insignificant, the positive coefficient of this variable is in line with positive accounting theory which stipulates that accounting conservatism is used to defer tax cost into the future. This study therefore fails to reject the fourth hypothesis

\section{Proportion of Female Directors and Tax Avoidance: The Moderating Role of Accounting Conservatism}

Contrary to a-priori expectation, the coefficient of FEMCON is still significantly positive. This suggests that accounting conservatism significantly moderate the effect of proportion of female directors on tax avoidance. This also implies that proportion of female directors significantly affect tax avoidance in firms with conservative accounting practice. In other words, the tax avoidance increases with the increase in female directors on the boards of firms with conservative accounting practice. This finding is consistent with the positive accounting theory which stipulates that accounting conservatism is used to defer tax cost into the future. Based on this, hypothesis five is rejected.

\section{Presence of a Female Director in the Audit Committee and Tax Avoidance: The Moderating Role of Accounting Conservatism}

The coefficient for FDADCON is positively significant at 10 percent. This suggests that accounting conservatism significantly moderates the effect of female director presence in audit committee on tax avoidance. This implies that the female directors' presence in the audit committee significantly affect tax avoidance in firms with conservative accounting practice. In other words, accounting conservative firms with female in the audit committee engage in tax avoidance practice. The evidence provided is consistent with the positive accounting theory which stipulates that accounting conservatism is used to defer tax cost into the future. This provides sufficient reason to reject the sixth hypothesis.

\section{Control Variables and Tax Avoidance}

The result shows that firm size has significant effect tax avoidance across models. Consistent with apriori expectation, the coefficient is positive. The 
result suggests that tax avoidance increase as firms becomes larger. This is line with political cost hypothesis that larger firms may understate revenue to avoid political cost associated with government interference due to increased profits. This result is consistent with previous findings of Rego (2003) and Minick and Noga (2010).

Consistent with a-priori expectation, the coefficient for leverage is negative and significantly affects tax avoidance across all models. This suggests that highly levered firms do not engage in tax avoidance activities. The rationale is because firms prefer debt financing rather than equity financing due to interest deductibility associated to financing through leverage. The evidence provided is consistent with that of Richardson and Lanis (2015). Similarly, the coefficient for board size is negative and significantly affects tax avoidance across all models. This implies that tax avoidance increase as board size increases. Evidence provided is contrary to that of Ribeiro, Cerqueira and Brandão (2015).

\section{Moderating Variable and Tax Avoidance}

The result in Table 10 shows that accounting conservatism has a significant negative effect on tax avoidance across all models. This suggests that accounting conservative firms less engage in tax avoidance practice. The result implies that accounting conservative firms report less book tax difference. Frank et al. (2004) reported that book tax differences increased with the higher earnings management. Therefore, it is expected that the accounting conservatism would be associated with less book tax differences. This may be due to the measure of accounting conservatism utilised in this study which is unconditional accounting conservatism.

\section{Sensitivity Analysis}

This study utilises Blau index as another proxy for board gender diversity which covers the combination of women and men on the board. It measures how evenly male and female directors are represented or the level of board heterogeneity. Blau index ranges from 0 to 0.5 . Therefore, Blau index values closer to 0.5 indicates more diverse board and closer values to 0 indicates less board diversity. The Blau index is measured as given below:

$$
B L A U=1-\Sigma p_{i}^{2}
$$

where $p_{i \text { is }}$ proportion of women to men for firm $i$ at time $t$

This measure is used to replace female CEO, percentage of female directors and presence of female in the audit committee in testing the effect of board 
diversity on corporate tax avoidance. The model below also accounts for the moderating role of accounting conservatism.

$$
\begin{aligned}
\text { TBTD }_{i t}= & \alpha_{0}+\beta_{1} G D_{i t}+\beta_{2} P R O F_{i t}+\beta_{3} F S_{i t}+\beta_{4} L E V_{i t}+\beta_{5} B S_{i t}+ \\
& \beta_{6} C O N_{i t}+\beta_{7} G D * C O N_{i t}
\end{aligned}
$$

It is expected that a diverse board will negatively affect corporate tax avoidance practice which is captured by $\beta_{l}$. This effect is expected to diminish for conservative accounting firms which is represented by $\beta_{7}$. The table below shows the result of the regression of Blau Index of diversity on corporate tax avoidance.

The result in Table 11 provides support for the initial result. Consistent with the initial findings on female CEO and percentage of female directors on the board, the coefficient for gender diversity is positive and significant at five percent. This is contrary to a-priori expectation that gender mix on the board will reduce corporate tax avoidance. The result provides additional support that gender diversity directors on the board leads to corporate tax minimization. Similarly, the moderating effect of accounting conservatism on the relationship between gender diversity and corporate tax avoidance is positive and significant at 10 percent. This implies that the board gender diversity significantly affects corporate tax avoidance for firms adopting conservative accounting practice. Gender diversity in the boardroom explains 59.50 percent of corporate tax avoidance practice in listed manufacturing firms while the model is fit at one percent level of significance.

Table 11

Gender Diversity and Corporate Tax Avoidance

\begin{tabular}{lcl}
\hline Variable & Predicted Sign & Coefficient/t.Statistics \\
\hline Intercept & - & $-0.514 /-4.25$ \\
GD & - & $0.138 / 2.39 *$ \\
Profitability & - & $0.229 / 3.27$ \\
Firm size & - & $0.078 / 4.51$ \\
Leverage & + & $-0.142 /-4.23 *$ \\
Board size & - & $-0.006 /-1.38$ \\
Cons & + & $-0.074 /-0.74$ \\
GDCONS & + & $0.734 /-4.25$ \\
$\mathrm{R}^{2}$ Within & 0.5950 & \\
F. Statistics & $115.26 * * *$ & \\
\hline Note: $* * *$ and $* * *$ denote statistically significance at $10 \%, 5 \%$ and $1 \%$ respectively.
\end{tabular}




\section{Theoretical and Policy Implication of the Study}

The findings of this study are contrary to the literature on organisational behaviour that women are generally risk-averse. That is, when faced with conflicting courses of action, they rather chose the alternative which is less risky. Prior studies suggest female directors reducedthe earnings management due to being less risk tolerant compared to their male counterparts. The evidence provided suggests that female risk aversion hypothesis cannot be extended to tax avoidance practice as a risk-taking behaviour. Also, it shows that women in the boardroom improve bottom line financial performance.

The findings from this study have several policy implications. The results show that little number of firms has female CEO throughout the study period. Given that the female CEO positively affects tax savings, the firms in Nigeria should consider gender balance at the top of the board structure. There is no legislation concerning what should be the appropriate gender ratio of board members. The findings from this study show that Nigerian female directors are risk loving and assertive in influencing accounting outcomes. This shows that they are not tokens and inferior to their male counterparts. Emphasis should therefore be on mandatory gender balance in the boardroom. In Nigeria, directors to be nominated into the audit committee must be nonexecutive. The result from this study shows that the provision of the code can be extended to include female non-executive directors since the membership from the angle of the shareholders may be totally males. This will ensure gender balance in the audit committee.

\section{Conclusion}

This study investigated the effects of female in governance on tax avoidance in listed manufacturing firms in Nigeria. It was noted that prior researches on tax avoidance in Nigeria, either centred on board or firm characteristics and that little is known about how gender composition affects tax avoidance. The attempt by this study was on the premise of filling the gap between the accounting income and taxable profits of listed manufacturing firms. The study has attempted to focus on examining whether gender differences in the boardroom explains such gap.

The panel corrected standard regressions technique was utilised in examining the effects of female CEO, percentage of female directors and presence of female in the audit committee after moderating for the role of accounting conservatism. The three proxies for females in governance have significant positive effect on tax avoidance. Moderating for accounting conservatism, 
the effect of female $\mathrm{CEO}$ on tax avoidance became insignificant. The percentage of female directors on the board and female director presence in the audit committee remains significant despite the inclusion of accounting conservatism as a moderating variable.

The result from this study shows that accounting conservatism limit tax avoidance practice. The result on the moderating variable suggests that it limits book tax differences. Contrary to the earnings management, this suggests that accounting conservatism can be used as a tool to disciple managers thereby improving the integrity of financial reporting. This is important for financial and tax regulators and standard settlers who are interested in the connection between financial and tax reporting decisions.

\section{Acknowledgement}

This research received no specific grant from any funding agency.

\section{References}

Adhikari, B. K., Agrawal, A.,\& Malm, J. (2015). Do women stay out of trouble? Evidence from corporate litigation. Assessed on $29^{\text {th }}$ of January, 2020 from https:www.ssrn.com

Aisha M. (2017). Effect of corporate governance mechanisms on tax avoidance (Unpublished dissertation thesis). Ahmadu Bello University, Zaria.

Ball, R. (2001). Infrastructure requirements for an economically efficient system of public financial reporting and disclosure. BrookingsWharton papers on financial services, 127-169.

Berggren, J., \& Gonzalez, R. (2010). Gender difference in financial decision making. https:www.ssrn.com

Boots, M., (2015). Female representation in top management and (aggressive) corporate tax avoidance. https:www.ssrn.com

Boussaidi, A., \& Hamed, M. S. (2015). The impact of corporate governance mechanism on tax aggressiveness: Empirical evidence from Tunisian context. Asian Economic and Social Society, 5(1).

Byrnes, J., Miller, D. C.,\& Schafer, W. D. (1999). Gender differences in risk taking: A meta-analysis. Psychological Bulletin, 125, 367-383.

Carter, David A., Betty J. Simkins., \& Simpson, W. G. (2003). Corporate governance, board diversity, and firm value. Financial Review, 38(3), 33-53.

Christensen, D. M., Dhaliwal, D. S., Boivie, S., \& Graffin, S. D. (2014). Top management conservatism and corporate risk strategies: Evidence 
from managers' personal political orientation and corporate tax avoidance. https:www.ssrn.com

Chyz, J. A., Gaertner, F. B., Kausar, A., \& Watson, A. (2015). Overconfidence and corporate tax policy. https:www.ssrn.com

Duellman, (2004). Evidence of the role of conservatism in corporate governance. https:www.ssrn.com

Garcia, L., Beatriz, G. O., \& Penalva, F. (2005). Board of directors characteristics and conditional accounting conservatism: Spanish evidence. https:www.ssrn.com

Givoly, D., \& Hayn, C. (2000). The changing time-series properties of earnings, cash flows and accruals: Has financial reporting become more conservative? Journal of Accounting \& Economics, 29(3), 287-320.

Francis, B., Hasan. I., Park, J. C., \& Wu, Q. (2014). Gender differences in financial-reportingdecision: Evidence from accounting conservatism. Bank of Finland Research Discussion Papers. https:www.ssrn.com

Francis, B., Hasan. I., Wu. Q., \& Yan, M. (2014). Are female CFOs less tax aggressive? Evidence from tax aggressiveness. Bank of Finland Research Discussion Papers. https:www.ssrn.com

Frank, M. M., Lynch, L. J., \& Rego, S. O. (2004). Does aggressive financial reporting accompany aggressive tax reporting (and vice versa)? https:www.ssrn.com

Ho, S.S.M., Li, A.Y., Tam, K., \& Zhang, F.F. (2014). CEO gender, ethical leadership, and accounting conservati sm. Journal of Business Ethics. https:www.ssrn.com

Ismail, K. N. I. K.,\& Abdullah, S. N. (2013). Does women representation on the board and audit committees restrict earnings management? The impact of family ownership in Malaysian firms. https:www.ssrn.com

Jin, C., \& Cheng, D. (2013). Tax avoidance motivation effect on accounting conservatism (Unpublished Master Thesis). Lanxhou Commercial College. https:www.ssrn.com

Kasipillai, J., \& Abdul Jabbar, H. (2006). Gender and ethnicity differences in tax compliance. Asian Academy of Management Journal, 11(2), $73-88$

Katz, S., Khan, U., \& Schmidt, A. P. (2013). Tax avoidance and future profitability. https:www.ssrn.com

Kelly, O. S., (2005). Taxes, conservatism in financial reporting and the value relevance of accounting information. University of Washington. https:www.ssrn.com

Khaola, A., \& Ali, M. Z. (2012). Demographic diversity and corporate tax planning in American firms. Macrothink Institute, Business and Management Strategy, 3(1).

Kim, B., \& Jung, K., (2007). The influence of tax costs on accounting conservatism. Korea Advanced Institute of Science and Technology. https:www.ssrn.com 
Krishnan, G. V., \& Parsons, L. M. (2008). Getting to the bottom line: An exploration of gender and earnings quality. Journal of Business Ethics, 78(1-2), 65-76.

Mariem, K., Trabelsi, S., \& Matoussi, H. (2012). Conditional conservatism in U.S. high- and low-technology firms. https:www.ssrn.com

Minnick, K., \& Noga, T. (2009). Do corporate governance characteristics influence tax management. http://www.researchgate.net/publication 222647457

Novita, N. (2016). Executive characters, gender and tax avoidance: Study of manufacturing companies in Indonesia. www.ssrn.com

Olayinka, E., Oyenike, O., \& Francis, E. (2016). Female directors and tax aggressiveness of listed deposit money banks in Nigeria. Third International Conference on African Developmental Issues.

Palvia, A., Vähämaa, E., \& Vähämaa, S. (2014). Are female CEOs and chairwomen more conservative and risk averse? Evidence from the Banking Industry during the Financial Crisis. Journal of Business Ethics, 6(2).

Parrotta, P., Smith, N. (2013). Female led firms: Performance and risk attitudes. University of Lausanne, IZA. https:www.ssrn.com

Qiang, X. (2007). The effects of contracting, litigation, regulation, and tax costs on conditional and unconditional conservatism: Cross-sectional evidence at the firm level. The Accounting Review, 82(3), 759-796

Rahimipour, A. (2017). Investigation of the impact of women's representation and participation on board of directors on tax avoidance in listed companies on the Tehran stock exchange (TSE). http://www.sciarena. com

Rego, S. O. (2003). Tax-avoidance activities of U. S. multinational corporations. Contemporary Accounting Research, 20(4), 805-833.

Ribeiro, A., Cerqueira A., \& Brandao, E. (2015). Determinants of effective tax rates: Firm characteristics and corporate governance. http:// www.ssrn.com

Richardson, G., Taylor, G., \& Lanis, R. (2015). Women on the board of directors and corporate tax aggressiveness in Australia: An empirical analysis. Accounting Research Journal, 29(3), 313-331.

Seyyedi, J. (2014). The effect of accounting conservative and tax income on tax avoidance. https://ssrn.com/abstract=2597578

Streefland, L. M. (2016). Gender board diversity and corporate tax avoidance: Does female board participation influence the level of corporate tax avoidance in public firms? Eramus School of Economics. https:www.ssrn.com

Wang, L. (2015). Board gender diversity and accounting conservatism: Evidence from Finland. Oulu Business School. https:www.ssrn.com 
Watts, R.L., (2003). Conservatism in accounting Part I: Explanations and implications. Accounting Horizons, 17, 207-221.

Yang, Ya-Wen., \& Kelton, A. (2015). CFO gender, board gender diversity and corporate tax evasion. Wake Forest University School of Business.

Yongbo,Li.(2014).Tax-inducedearningsmanagement, auditorconservatism, and tax enforcement (Unpublished Master Dissertation). Lingnan University. https:www.ssrn.com 